\title{
保育園での子どもの声の騒音問 QUESTIONNAIRE SURVEY ON 題に関する市民意識調査結果 CHILDREN PLAYING NOISE IN NURSERY SCHOOL
}

橋本典久 — $* 1 \quad$ 安部信行 - - $* 2$

キーワード :

保育園，子どもの遊び声，アンケート調査，市民意識

Keywords:

Nursery school, Children playing noise, Questionnaire survey, Citizen consciousness

\section{Norihisa HASHIMOTO $-* 1 \quad$ Nobuyuki ABE $-* 2$}

A questionnaire survey on the children playing noise in nursery schools was carried out as a target for general citizens in Tokyo and the other prefectures. The survey collection rate is $17.7 \%$ and the number of questionnaires collected is 341 . The results show that a rate of the persons opposing the construction of nursery schools is about $10 \%$, and the reason of opposition for the construction is only feeling of an anxiety for the children playing noise. If the anxiety can be then dispelled, it is possible to resolve this problem.

\section{1.はじめに}

保育園の新規建設が近隣住民の反対によって中止や延期になる事 例が多く発生し、待機児童問題への影響等から社会的にも大きな関 心事となっている。これに伴い、東京都では 2017 年に環境確保条例 の改正を行い、保育園等からの子どもの声を騒音の規制対象から外 した。大阪府では 2019 年に、子ども施設と地域の共生を図るための 手引書 ${ }^{1)}$ を作成するなど、各自治体が夫々の取り組みを始めている ものの、具体的な解決方法は今だ見当たらず、当事者はこの状況に 困惑するばかりとなっている。

保育園建設の反対理由には、子どもの声やイベントなどの騒音問 題、登降園時の交通の問題、砂ぼこりや施設からの臭いなどがある が、最も大きな理由は、園庭で遊ぶ子どもの声である。筆者らは、 保育園 10 施設を対象として園庭遊び時の子じもの声の騷音測定を 実施し、その大きさや周波数特性、対策としての防音塀の効果など 音響的なデーターを明らかとした ${ }^{2)}$ 。これにより、騒音の大きさに 関する客観的な検討は可能となったが、音の問題は物理的な条件だ けでは解決せず、人間の心理的要素も大変に大きな要因となる。

解決策を探る基礎的条件として、この問題に対して一般市民がど のような意識を持っているかを把握することは大変に重要であるが、 これまでその種の調查研究は殆どなされていない。厚生労働省が行 った「人口減少社会に関する意識調查」3) の中で、これに関する質 問調査が一問だけ行われ、近隣住民の苦情や立地反対に同感できる と答えた人が 3 割強に上ったことが報告されているが、それ以外の 詳細な調查は特に行われておらず、また、保育園建設問題に焦点を 当てた調査も全く行われていない。

今回、首都圈の戸建住宅居住者を対象として、当該問題に対する 市民の意識調査を実施した。本調査は、市民の意識を知って問題の
解決策を探るための基礎調査であり、そのため分析型のアンケート 調査を目指した。以下に、その調查結果を示す。

\section{2. アンケート調査内容}

\section{1 調査地域および回答数}

調查概要を以下に示した。首都圈 1 都 3 県の 40 地域を選定し、 各々に 50 通を配布した。用途地域は予め調べて調整の上、配布地域 を決定した。回答数は多いとは言えないが、統計的には十分に実態 を把握できる数值であると考える。

・調查名称：「地域社会の騒音問題に関寸る市民意識調查」

（注：保育園問題をあまり意識させないよう、この名称とした）

- 対象地域：東京、神奈川、埼玉、千葉の各 10 地域、計 40 地域

- 対象住宅：1 1 戸建住宅

・配布方法：配布は各戸にポスティング、回収は郵送

- 調查時期： 2016 年（平成 28 年） 8 月 8 日 10 日に質問票配布 回収期間は 2 ヶ月

-用途地域： 第 1 種低層住居専用地域から準工業地域まで

・配 布 数： 1927 通（40 地域に各 50 通の予定が、一部未配布）

- 回 答 数：341 通（回収率 $17.7 \%$ )

\section{2 質問内容}

質問内容は表 1 の通りである。アンケートは選択形式で、各質問 に回答項目が用意されているが、ここでは紙面の都合で省略した。 質問の主な内容は、騒音問題の認識、居住者の地域状況、子どもの 遊び声に対する意見、保育園の建設立地に対する意見、心理要素、 回答者属性などの全 36 問である。なお、用途地域は選定の上で用紙 を配布しているので、質問項目には含まれていない。参考までに、 自由記述の回答欄も用意した。

\footnotetext{
騒音問題総合研究所・代表 八戸工業大学名誉教授

(下039-1111 八戸市東白山台 4-5-3)

八戸工業大学・感性デザイン学科 准教授
}

\footnotetext{
I Representative, General Research Laboratory of Noise Problem, Prof. Emeritus, Hachinohe Institute of Technology

Assoc. Prof., Hachinohe Institute of Technology
} 


\section{3 回答状況および回答者の属性}

各都県の回答数は表 2 の通りであり、概放 均等となっている。用途地域毎の回答比率は 表 3 の通りであり、住居系（住専+住居地域） が計 $61.0 \%$ 、商業系（商業十近隣商業）が計 $30.5 \%$ 、工業系が $8.5 \%$ となっている。

回答者の属性は図 1 に示す通りであり、特 に偏った傾向は見られず、ほぼ現状を反映し た分布となっていると考えられる。男性、女 性はほぼ半分、年代では 60 代、70 代がやや多 いが、現実にも保育園問題で関与の大きい年 代であることから、これも適正な分布傾向で あると考えられる。

\section{表 2 各都県の回答状況}

\begin{tabular}{|c|c|}
\hline 地域 & 回答数 \\
\hline \hline 東京都 & 80 \\
\hline 埼玉県 & 90 \\
\hline 神奈川県 & 92 \\
\hline 千葉県 & 79 \\
\hline 計 & 341 \\
\hline
\end{tabular}

\section{表 3 用途地域別の回答状況}

\begin{tabular}{|l|c|}
\hline 用途地域 & 全体比率 (\%) \\
\hline \hline 1 種低層住専 & 16.7 \\
\hline 1 種中高層住専 & 11.1 \\
\hline 2 種中高層住専 & 5.0 \\
\hline 1 種住居地域 & 24.0 \\
\hline 2 種住居地域 & 4.1 \\
\hline 商業地域 & 25.5 \\
\hline 近隣商業地域 & 5.0 \\
\hline 準工業地域 & 8.5 \\
\hline
\end{tabular}

\section{3. アンケート集計結果}

\section{1 単純集計結果}

各質問に対する主な回答結果を図化したものを以 下に示す。単一選択回答に関しては、回答の比率を 円グラフで、複数回答に関しては、回答者全体に関 する比率を棒グラフで示した。

1）まず、図 2 に示すように、「近隣騒音問題は重大 な社会問題だと思いますか」の問いでは、「そう思う」 が $60.2 \%$ 、「どちらとも言えないが $33.8 \%$ 、「そう は思わないが $5.9 \%$ と、予想以上に近隣騷音問題を 重大な問題と捉えていることが分かった。この結果
表 1 アンケートの質問内容

\begin{tabular}{|c|c|}
\hline No. & 質問内容 \\
\hline Q0 & （用途地域）[質問外] \\
\hline Q1 & 近隣騒音問題は重大な社会問題だと思いますか。 \\
\hline Q2 & 近隣騒音トラブルが増加していますが、その原因は何だと思いますか。(複数回答) \\
\hline Q3 & これまで近隣からの騷音を迷惑に感じたことはありますか。 \\
\hline Q4 & （上記で「ある」と答えられた方への質問）それは、どんな騒音ですか。(複数回答） \\
\hline Q5 & 近隣騒音問題が事件などの深刻なトラブルにまで発展する要因は何だと思いますか。(複数回答) \\
\hline Q6 & あなたの住んでいる所は静かな所ですか、騒がしい所ですか。 \\
\hline Q7 & あなたの住んでいる所では、地域の行事や共同作業などがよく行われていますか。 \\
\hline Q8 & あなたの住んでいる所は、人口密度の多い所ですか、少ない所ですか。 \\
\hline Q9 & こどもの遊ぶ声も騷音だと思いますか。 \\
\hline Q10 & 子どもが大きな声を出して遊ぶことは、心身の発達に大切であると思いますか \\
\hline Q11 & 今後、社会的方策として保育園の数を増やしてゆく必要があると思いますか。 \\
\hline Q12 & あなたの自宅の横に保育園ができるとすると、騒音に対する不安を感じますか。 \\
\hline Q13 & 保育園建設に近隣住民が反対する事例が増えていますが、これをどう思いますか。 \\
\hline Q14 & この問題を解決するためには、何が有効だと思いますか。(複数回答) \\
\hline Q15 & 保育園側は近隣対策として、何をするべきだと思いますか。(複数回答) \\
\hline Q16 & 保育園側は騒音対策として、具体的に何をするべきだと思いますか。(複数回答) \\
\hline Q17 & 保育園の立地に関して、近隣住民が我慢することも必要だと思いますか。 \\
\hline Q18 & 保育園からの子どもの声の騷音に関して、近隣住民が我慢することも必要だと思いますか。 \\
\hline Q19 & 保育園や幼稚園などは迷惑施設だと思いますか。 \\
\hline Q20 & 静かな住宅地には、保育園や幼稚園を建てるべきではないと思いますか。 \\
\hline Q21 & 保育園や幼稚園などが隣にできることにより、土地の資産価値が下がることがあると思いますか。 \\
\hline Q22 & 仮に、あなたの家の隣に保育園建設計画が起こったらどうしますか。 \\
\hline Q23 & あなたが絆を感じるものは何ですか。(複数回答) \\
\hline Q24 & 人間は信用できると思いますか。 \\
\hline Q25 & 周りの人は自分の感じ方や考え方を分かってくれていると思いますか \\
\hline Q26 & 人間は、本来、一人ぼっちなのだと思いますか \\
\hline Q27 & お隣の方とは仲がよいですか \\
\hline Q28 & 地域社会に属しているという感じがありますか \\
\hline Q29 & 将来のことを考えると不安になりますか \\
\hline Q30 & 日頃から漠然とした不安感がありますか \\
\hline Q31 & 日々、平穏に暮らしたいと思っていますか。 \\
\hline Q32 & あなたの性別は、どれですか。 \\
\hline Q33 & あなたの年代は、どれですか。 \\
\hline Q34 & 現在の住居での居住歴はどれくらいですか。 \\
\hline Q35 & 仕事をされていますか。 \\
\hline Q36 & 同居の家族構成として当てはまるものは、どれですか。 \\
\hline
\end{tabular}

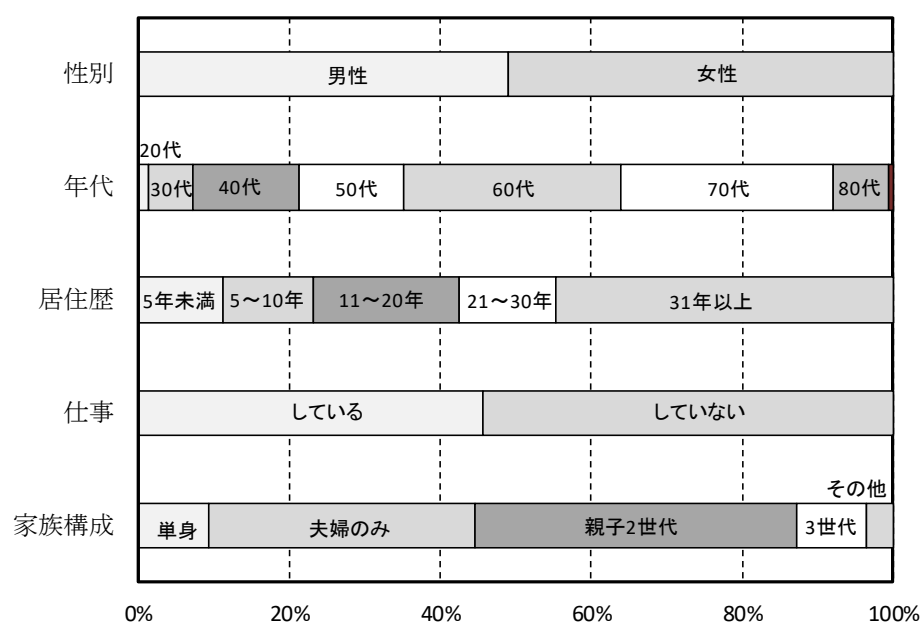

図 1 回答者の属性一覧 
に呼応して、「これまで近隣からの騒音を迷惑に感じたことはありま すか」（図省略）では、「ある」が $54.5 \%$ 、「ないが $45.5 \%$ と、僅か ではあるが「ある」と答えた人が上回った。近隣騒音問題が益々大き な問題となっていることを裏付ける結果となっている。

2）迷惑に感じた騒音の種類（複数回答）は、図 3 に示すように車 のエンジン音・アイドリング音が最も多く $23.2 \%$ であった。この傾 向は昔から同じであり、予想通りであった。2 番目が犬の鳴き声の $15.5 \%$ であり、そして、3 番目が子どもの声（遊び声、泣き声など） で $12.3 \%$ であった。店舗やカラオケなどの営業騒音や、テレビ、ス テレオなどの音、エアコン室外機などを抑えての 3 位であり、保育 園の建設反対運動が多くなっているのが領ける結果となっている。 一方、「子どもの遊ぶ声も騒音だと思いますか」の問いでは、「騒音で ある」と答えた人は $1.5 \%$ に過ぎず、「ある程度、大きな場合は騒音 だ」が $27.4 \%$ となっている。騒音の大きさが抑えられれば、問題が 解消する可能性があることが示唆されている。

3）保育園問題に関する質問では、「子どもが大きな声を出して遊ぶ ことは、心身の発達に大切であると思いますか」に対して、「非常に 大切だと思う」が $33.2 \%$ 、「大切だと思う」が $58.2 \%$ で併せて $91.4 \%$ にのぼった。ちなみに「全く思わないは」は０\%であった。大変に泠 静な回答である。また、「保育園や幼稚園などは迷惑施設だと思いま すか」(図省略)に対しても、「思わないかが $78.1 \%$ 、「どちらとも言 えない」が $20.4 \%$ 、「思う」は僅か $1.5 \%$ と、これも比較的好意的な結 果となっている。その一方、「あなたの自宅の横に保育園ができると すると、騒音に対する不安を感じますか」（図 6 ) では、「大いに感 じる」が $10.7 \%$ 、「少し感じる」が $36.4 \%$ と、併せて $47.1 \%$ となり、 半分近くの人が不安を持っていることが分かる。この不安を解消寸 ることが問題解決の第一歩になるということであり、大変に重要な 結果である。

4）「今後、社会的方策として保育園の数を増やしてゆく必要がある と思いますか」(図省略) の問いで、「大いにある」は $52.2 \%$ 、また、 「静かな住宅地には保育園を建てるべきではない」（図省略）という 意見は $9.8 \%$ に過ぎず、 $49.7 \%$ の人は、そうは思わないと答えてい る。保育園の必要性が広く認識されている結果であると考えられる。

5）「仮に、あなたの家の隣に保育園建設計画が起こったらどうしま すか」（図 7 ）では、「強く反対する」が $3.3 \%$ 、「反対する」が $7.1 \%$

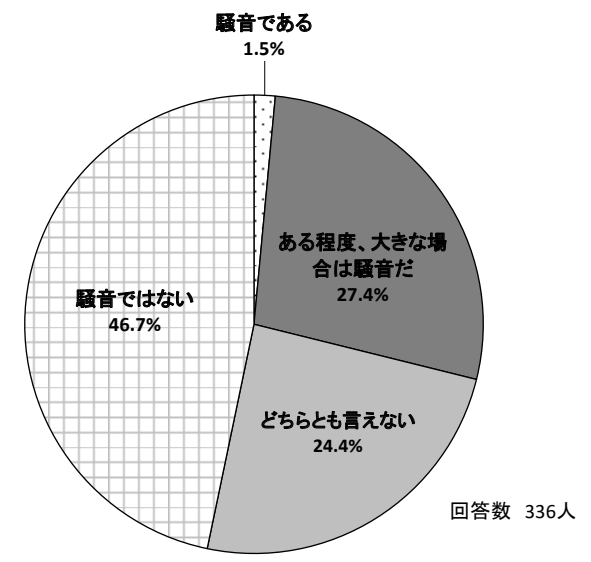

Q9:こどもの遊ぶ声も騒音だと思いますか。

図4 単純集計結果 (3)
と、合計で約 10\%が反対であった。「特に反対しない」 $56.5 \%$ 、「歓 迎寸る」が 8.6\%であるから、反対しないという方が圧倒的に多い。 しかし、その他の結果も合わせて、現在は、比率で言えば約 10\% (「強 く反対する」に限れば $3 \%$ 程度）の反対意見が結果を左右する状況と なっており、状況改善の余地が大きいといえる。

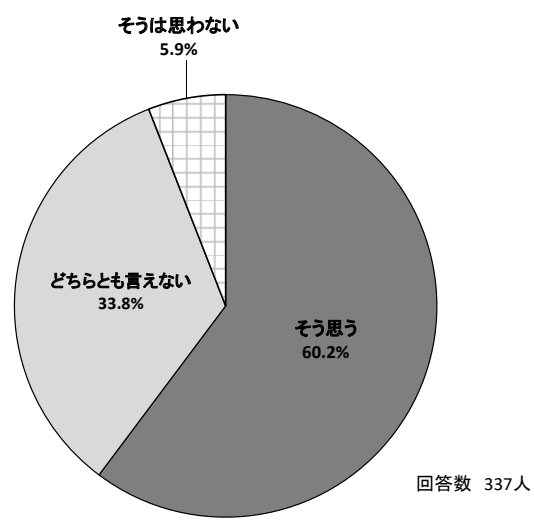

Q1: 近隣騷音問題は重大な社会問題だと思いますか.

図 2 単純集計結果 $(1)$

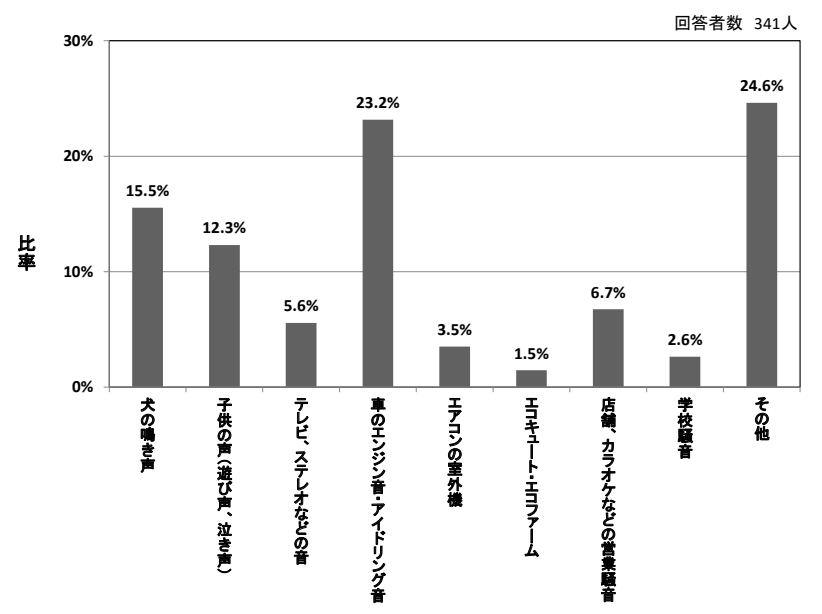

Q4: (上記である」と答えられた方への質問) それは、どんな騒音ですか。(複数回答) 図 3 単純集計結果 (2)

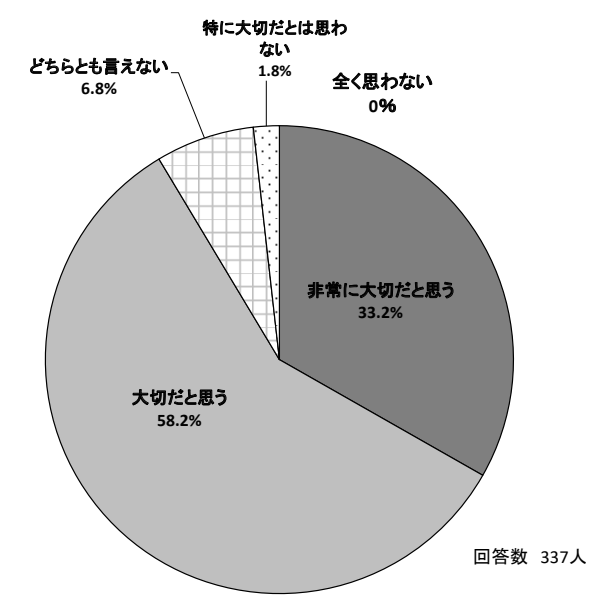

Q10:こどもが大きな声を出して遊ぶことは、心身の発達に大切 であると思いますか。

図 5 単純集計結果 (4) 


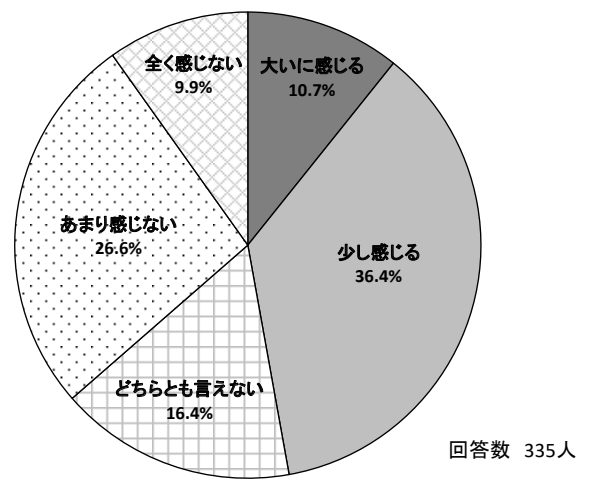

Q12: あなたの自宅の横に保育園ができるとすると、 騒音に対する不安を感じますか。

図 6 単純集計結果 $(5)$

\section{2 相関分析結果}

表 1 に示す質問項目に関する回答間の相関分析を行った結果を表 4 に示した。この結果、相関係数 0.6 以上の相関関係が見られたも のは、 Q 9-Q 12 (相関係数 0.60 、以後数值のみ示寸)、 Q 12 -Q $13(0.64) 、 \mathrm{Q} 12$-Q 22 (0.6 1)、Q 13 -Q 22 (0.62)、 Q 17 -Q 18 (0.75)、Q 20 -Q 22 (0.60)の 6 ケースであり、 何れも正の相関である。これらの結果を含めて、相関分析により得 られた内容を整理すると以下の通りである。

1）保育園建設に関する諸質問と用途地域に関する相関は全く見ら

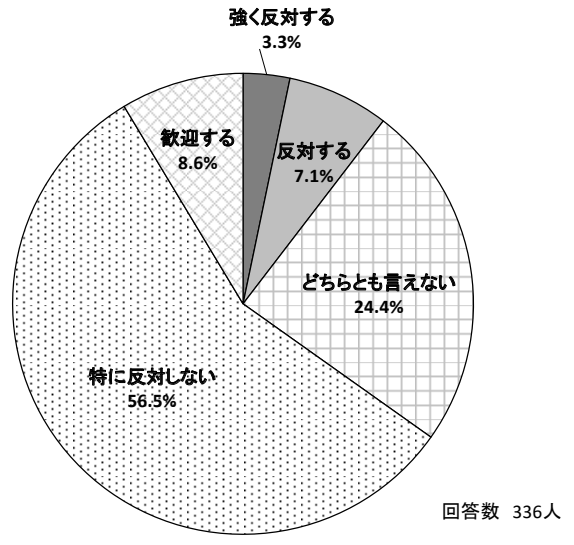

Q22: 仮に、あなたの家の隣に保育園建設計画が起こったらどう しますか。

\section{図 7 単純集計結果 $(6)$}

れなかった。同様に、住んでいる所が静かな所かうるさいところか、 人口が多い所か少ない所かについても全く相関が見られなかった。 これまで、静かな所に住んでいる人ほど保育園の立地等に反対する 傾向があると考えていたが、保育園建設に反対するかどうかは、地 域状況には関係なく、ひとえに個人の考え方次第ということになる。 2）年代、性別、居住歴の長さ、仕事の有無、単身を含めた家族構 成などと、保育園建設への反対意見にも全く相関関係は見られなか った。

3）自宅の隣に保育園建設計画が起こったら反対すると答えている

表 4 各回答間の相関係数（相関係数 0.6 以上を墨塗り）

\begin{tabular}{|c|c|c|c|c|c|c|c|c|c|c|c|c|c|c|c|c|c|c|c|c|c|c|c|c|c|c|c|c|c|c|}
\hline & Q0 & Q1 & Q3 & Q6 & Q7 & Q8 & Q9 & Q10 & Q11 & Q12 & Q13 & Q17 & Q18 & Q19 & Q20 & Q21 & Q22 & Q24 & Q25 & Q26 & Q27 & Q28 & Q29 & Q30 & Q31 & Q32 & Q33 & Q34 & Q35 & Q36 \\
\hline Q0 & 1.00 & 0.01 & -0.01 & 0.24 & 0.01 & -0.28 & 0.00 & 0.00 & -0.06 & 0.01 & -0.01 & 0.00 & 0.01 & -0.01 & 0.07 & 0.07 & 0.06 & 0.01 & 0.03 & 0.01 & 0.05 & 0.02 & -0.03 & 0.00 & -0.05 & -0.01 & -0.04 & -0.09 & -0.10 & 0.16 \\
\hline Q1 & & 1.00 & -0.19 & 0.05 & -0.11 & 0.04 & 0.28 & -0.09 & -0.01 & 0.31 & 0.24 & -0.14 & -0.12 & 0.14 & 0.16 & 0.10 & 0.18 & 0.05 & 0.09 & -0.03 & -0.02 & 0.00 & 0.04 & 0.08 & 0.09 & -0.09 & 0.01 & -0.02 & -0.03 & -0.01 \\
\hline Q3 & & & 1.00 & 0.05 & 0.05 & -0.09 & -0.21 & 0.11 & 0.12 & -0.21 & -0.22 & 0.08 & 0.09 & -0.17 & -0.16 & -0.17 & -0.21 & 0.15 & 0.03 & -0.06 & 0.06 & 0.00 & -0.09 & -0.12 & -0.03 & 0.16 & -0.03 & -0.02 & 0.03 & 0.02 \\
\hline Q6 & & & & 1.00 & 0.08 & -0.18 & 0.05 & 0.03 & 0.02 & 0.05 & 0.05 & -0.01 & -0.01 & 0.00 & 0.04 & 0.07 & 0.04 & 0.04 & 0.09 & 0.01 & -0.04 & 0.08 & 0.00 & 0.03 & 0.06 & -0.02 & 0.05 & -0.01 & -0.04 & -0.01 \\
\hline Q7 & & & & & 1.00 & 0.10 & -0.07 & 0.04 & -0.05 & -0.04 & -0.03 & 0.03 & -0.04 & 0.03 & 0.01 & -0.02 & -0.03 & 0.03 & 0.14 & 0.03 & 0.13 & 0.30 & 0.08 & 0.07 & -0.04 & -0.07 & 0.01 & -0.04 & 0.04 & -0.01 \\
\hline Q8 & & & & & & 1.00 & 0.02 & 0.09 & 0.08 & 0.00 & 0.03 & -0.07 & -0.09 & \begin{tabular}{|l|l}
0.04 \\
\end{tabular} & -0.06 & -0.02 & 0.05 & 0.08 & 0.07 & -0.10 & 0.02 & 0.01 & -0.02 & -0.09 & 0.02 & -0.02 & 0.07 & 0.11 & 0.06 & -0.06 \\
\hline Q9 & & & & & & & 1.00 & -0.38 & -0.15 & 0.60 & 0.56 & -0.22 & -0.26 & 0.32 & 0.38 & 0.42 & 0.50 & -0.02 & 0.00 & 0.16 & -0.06 & -0.10 & 0.21 & 0.23 & 0.08 & -0.11 & 0.07 & 0.04 & 0.02 & 0.01 \\
\hline Q10 & & & & & & & & 1.00 & 0.23 & -0.37 & -0.40 & 0.20 & 0.20 & -0.25 & -0.27 & -0.23 & -0.27 & 0.10 & 0.06 & -0.17 & 0.09 & 0.15 & -0.02 & -0.09 & 0.12 & -0.01 & 0.04 & 0.03 & 0.07 & -0.06 \\
\hline Q11 & & & & & & & & & 1.00 & -0.23 & -0.28 & 0.13 & 0.10 & -0.22 & -0.25 & -0.14 & -0.28 & 0.14 & 0.00 & -0.17 & 0.12 & 0.06 & 0.00 & -0.10 & 0.09 & -0.02 & -0.01 & 0.00 & 0.14 & 0.01 \\
\hline Q12 & & & & & & & & & & 1.00 & 0.64 & -0.23 & -0.29 & 0.35 & 0.46 & 0.45 & 0.61 & -0.04 & -0.04 & 0.24 & -0.08 & -0.04 & 0.20 & 0.24 & 0.08 & -0.12 & 0.08 & 0.05 & 0.03 & -0.05 \\
\hline Q13 & & & & & & & & & & & 1.00 & -0.38 & -0.44 & 0.40 & 0.51 & 0.49 & 0.62 & -0.06 & -0.07 & 0.20 & -0.12 & -0.05 & 0.15 & 0.20 & 0.09 & -0.14 & 0.09 & 0.07 & 0.03 & -0.03 \\
\hline Q17 & & & & & & & & & & & & 1.00 & 0.75 & -0.21 & -0.27 & -0.20 & -0.39 & 0.14 & 0.11 & -0.11 & 0.20 & 0.12 & -0.01 & 0.00 & 0.02 & 0.12 & -0.14 & -0.13 & -0.08 & 0.13 \\
\hline Q18 & & & & & & & & & & & & & 1.00 & -0.32 & -0.30 & -0.19 & -0.39 & 0.08 & 0.13 & -0.14 & 0.20 & 0.17 & -0.12 & -0.07 & 0.03 & 0.18 & -0.15 & -0.16 & -0.11 & 0.11 \\
\hline Q19 & & & & & & & & & & & & & & 1.00 & 0.43 & 0.35 & 0.44 & -0.05 & 0.00 & 0.05 & -0.15 & -0.19 & 0.10 & 0.21 & 0.02 & -0.07 & 0.05 & 0.03 & 0.05 & 0.00 \\
\hline Q20 & & & & & & & & & & & & & & & 1.00 & 0.49 & 0.60 & -0.02 & 0.04 & 0.05 & -0.13 & -0.02 & 0.09 & 0.16 & -0.03 & -0.06 & 0.03 & -0.03 & 0.02 & 0.02 \\
\hline Q21 & & & & & & & & & & & & & & & & 1.00 & 0.53 & -0.09 & -0.03 & 0.16 & -0.01 & 0.05 & 0.12 & 0.21 & -0.04 & 0.02 & -0.04 & -0.03 & -0.04 & -0.01 \\
\hline Q22 & & & & & & & & & & & & & & & & & 1.00 & -0.03 & -0.05 & 0.15 & -0.13 & -0.05 & 0.13 & 0.22 & 0.10 & -0.04 & 0.05 & 0.02 & 0.00 & -0.07 \\
\hline Q24 & & & & & & & & & & & & & & & & & & 1.00 & 0.46 & -0.13 & 0.17 & 0.24 & -0.22 & -0.16 & 0.04 & 0.06 & 0.06 & 0.15 & 0.10 & -0.03 \\
\hline Q25 & & & & & & & & & & & & & & & & & & & 1.00 & -0.17 & 0.24 & 0.33 & -0.22 & -0.20 & 0.02 & -0.06 & 0.08 & 0.09 & 0.07 & -0.10 \\
\hline Q26 & & & & & & & & & & & & & & & & & & & & 1.00 & -0.08 & -0.09 & 0.18 & 0.21 & -0.06 & -0.10 & 0.04 & \begin{tabular}{|l|}
0.02 \\
\end{tabular} & 0.04 & 0.10 \\
\hline Q27 & & & & & & & & & & & & & & & & & & & & & 1.00 & 0.45 & -0.09 & -0.14 & 0.04 & -0.04 & -0.11 & -0.04 & -0.05 & -0.02 \\
\hline Q28 & & & & & & & & & & & & & & & & & & & & & & 1.00 & -0.12 & -0.14 & \begin{tabular}{|l|}
0.02 \\
\end{tabular} & -0.04 & -0.18 & -0.12 & -0.12 & -0.02 \\
\hline Q29 & & & & & & & & & & & & & & & & & & & & & & & 1.00 & 0.72 & 0.16 & -0.18 & 0.07 & \begin{tabular}{|l|}
0.07 \\
\end{tabular} & 0.12 & 0.05 \\
\hline Q30 & & & & & & & & & & & & & & & & & & & & & & & & 1.00 & 0.18 & -0.08 & -0.01 & -0.02 & 0.05 & 0.08 \\
\hline Q31 & & & & & & & & & & & & & & & & & & & & & & & & & 1.00 & -0.09 & 0.10 & 0.08 & 0.03 & 0.00 \\
\hline Q32 & & & & & & & & & & & & & & & & & & & & & & & & & & 1.00 & -0.23 & -0.10 & -0.03 & 0.09 \\
\hline Q33 & & & & & & & & & & & & & & & & & & & & & & & & & & & 1.00 & 0.59 & 0.55 & -0.17 \\
\hline Q34 & & & & & & & & & & & & & & & & & & & & & & & & & & & & 1.00 & 0.40 & -0.12 \\
\hline Q35 & & & & & & & & & & & & & & & & & & & & & & & & & & & & & 1.00 & -0.15 \\
\hline Q36 & & & & & & & & & & & & & & & & & & & & & & & & & & & & & & 1.00 \\
\hline
\end{tabular}


人と、自宅の横に保育園ができるとすると騒音に対する不安を感じ るということには明確な相関が見られた（相関係数 0.61）。また、 その人達は、「子どもの声も騒音だ」という明確な意識を持っており (相関係数 0.60)、「保育園や幼稚園などは迷惑施設だ」とも思って いる。これらから、騒音に対する不安が大きな要素になっているこ とが改めて理解できる。また、その人たちの意見として、静かな住 宅地には保育園や幼稚園を建てるべきではないと考えているが、前 の結果と併せれば、静かな所に住んでいるからそう思っているので はなく、不安を持っているから静かな所には建てるべきでないと考 えていることが推察される。

4）「子どもが大きな声を出して遊ぶことは、心身の発達に大切であ ると思いますか」の問いに関して、大切であると答えた人ほど、騒音 に対する不安を感じる人の割合が少なくなっており、併せて、住民 が保育園建設に反対することに対して否定的な意見を持っていた。 これらからは、子どもが大きな声を出して遊ぶことが、心身の発達 に如何に大事かということをしっかりと説明できれば、反対を少し でも抑えられる可能性があると考えられる

5）東日本大震災の応急仮設住宅での調査 結果 ${ }^{4)}$ では、日常生活の不安感や孤独感と、 隣近所から聞こえてくる音をうるさく感じ ることに強い相関関係が見られたが、今回の 結果では、このような心理的な要素の影響は 殆ど見られなかった。ただ、かなり弱い相関 ではあるが、日頃から漠然とした不安感を感 じている人ほど、保育園の建設に反対する傾 向が見られた。

\section{3 クロス集計と $\chi 2$ 乗検定結果}

相関関係の見られた質問内容に関して、ク ロス集計により詳細な傾向を確認した。また、 併せて $x 2$ 乗検定により、有意差の評価を行 った。主な内容について以下に示す。

1）「仮に、あなたの家の隣に保育園建設計 画が起こったらどうしますか」という質問へ の回答に関して、回答者の属性との関係を調 べた。図8は一例として、居住歴との関係を クロス集計したものであるが、居住歴が長い

\section{表 5 保育園建設と回答者属性の関係}

\begin{tabular}{|c|c|}
\hline 条 件 & $\chi 2$ 乗検定 \\
\hline \hline 性 別 & 0.74 \\
\hline 年 代 & 0.63 \\
\hline 仕事の有無 & 0.63 \\
\hline 家族構成 & 0.16 \\
\hline 用途地域 & 0.71 \\
\hline
\end{tabular}

ほど保育園建設に反対するという傾向はみられない。この時の $\chi 2$ 乗検定值は $0.27(0.05$ 以下で分布に有意差あり、0.01 以下で明確 な有意差あり）であり、この数值からも明確な傾向がないことが示 されている。同様に、居住歴以外の回答者の属性と保育園建設反対 の関係を調べた結果を、 $x 2$ 乗検定值として表 5 に示したが、性別、 年代、仕事の有無、家族構成、用途地域の何孔に関しても明確な関 係は見られなかった。

2）次に、「仮に、あなたの家の隣に保育園建設計画が起こったらど うしますか」と、「あなたの自宅の横に保育園ができるとすると、騒 音に対する不安を感じますか」の関係をクロス集計したものを図 9 に示すが、ここでは極めて明確な傾向が示されている（ $x 2$ 乗検定 值 0.01 以下)。保育園建設計画に強く反対する人は、騒音に対する 不安を大いに感じている人が約 $90 \%$ であり、少し感じると合わせる と $100 \%$ にる。一方、不安を感じていない人は保育園建設を歓迎 する傾向さえある。先の結果と合わせれば、保育園建設に反対する 理由は、年代や居住歷、静かな所かそうでないかなどの条件には一

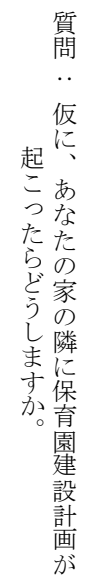

どちらとも言えない

特に反対しない

歓迎する

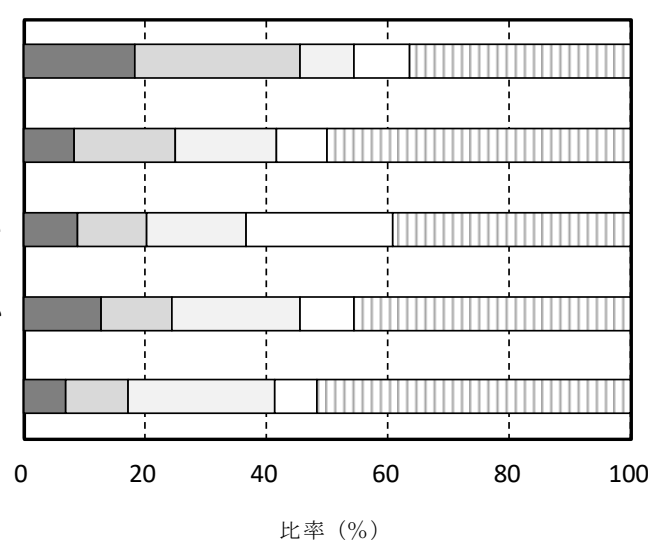

質問：現在の住居での居住歴はどれくらいですか

口5年未満

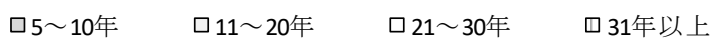

図8 保育園建設反対意見と居住歴の関係

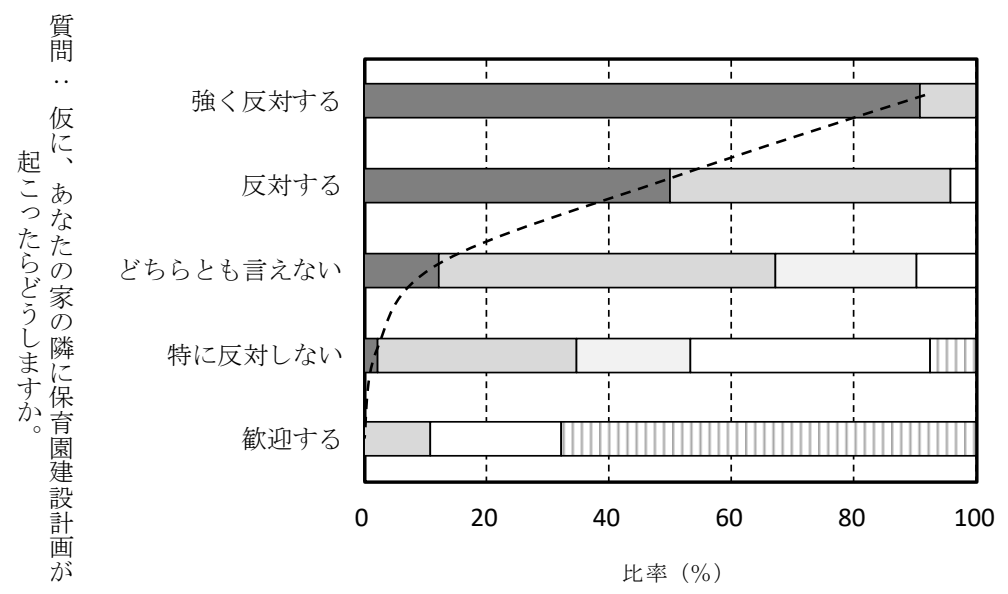

質問：あなたの自宅の横に保育園ができるとすると、騒音に対する不安を感じますか ロ大いに感じる ロ少し感じる ロどちらとも言えない ロあまり感じない口全く感じない

図 9 保育園建設反対意見と不安感の関係 
切関係なく、その人が保育園からの騒音に 対して不安を感じるかどうかで決定され るといえる。保育園建設反対の意見には、 交通関係の不安なども上げられるが、これ らの結果を見れば騒音に対する不安が最 も大きな要因であり、この不安を取り除く ことが出来れば、反対の人達を説得できる 可能性があることを示唆している。これは、 近隣対策などに関して大変に重要な知見 であると考える。

3）「仮に、あなたの家の隣に保育園建設 計画が起こったらどうしますか」と「静か な住宅地には、保育園や幼稚園を建てるべ きではないと思いますか」の回答もほぼ同 傾向であり（図 10、 $\chi 2$ 乗検定值 0.01 以 下)、騒音の不安を感じている人が、静か な所には保育園を建てるべきではないと いう意見を持っていることが分かる。

4）また、図 11 に示すように、「子どもが 大きな声を出して遊ぶことは、心身の発達 に大切であると思いますか」に関しては、 保育園建設に強く反対する人は、騒音に対 する不安があるため、非常に大切だとは思 っているが、建設には反対するという結果 となっている。強く反対する人以外に関し ては、心身の発達に大切であると考える人 が、保育園建設に好意的な態度を示す傾向 があるため、この点をしっかりと説明する ことは、住民説明会等に集まった人たちの 賛同を得るためには有効であると考えら れる。

5）保育園の新規建設は、住宅地などで計 画されることが多いため、建設反対の理由が用途地域などで決まる となると今後の立地の困難さが確定してしまう懸念があったが、今 回の調查結果により、保育園建設推進の可能性とそのための留意点 が示されたと考える。

\section{4. まとめ}

保育園からの子どもの声の騒音問題に関して一般市民がどのよう な意識を持っているかについて、首都圈の 1 都 3 県でアンケート調 查を実施した。これまで漠然と、保育園の建設に反対する人は、静 かな住宅地に長年暮らし、家にいる時間が長い高齢者というイメー ジを持ってきたが、調查の結果、用途地域、静かな場所かどうか、 居住歴、年齢、性別などには一切関係なく、保育園建設に反対する 主な理由は、保育園が出来た後の騒音に対する不安感を強く持って いるかどうかであることが明らかとなった。反対する人の比率は全 体の約 1 割であり、この人達の不安感を取り除くことが出来れば、 建設を円滑に進めることが出来る可能性があることが明らかとなっ た。そのためには、既報 ${ }^{2)}$ で示した子どもの声の大きさのデーター や防音塀などによる対策の効果を定量的に示し、その上で、丁寧な

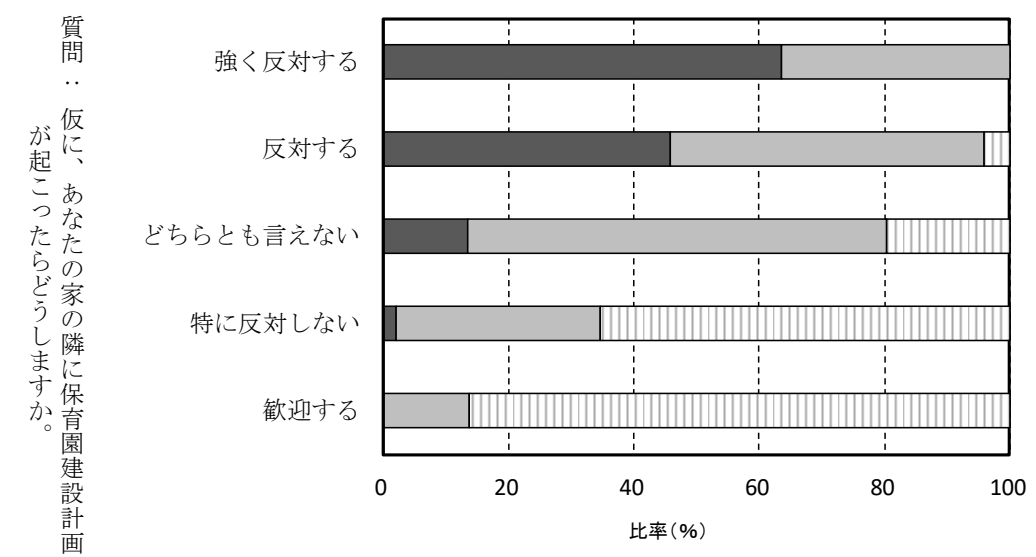

質問：静かな住宅地には、保育園や幼稚園を建てるべきではないと思いますか。

ロ思うロロどちらとも言えない、思わない

図 10 保育園建設反対意見と建設場所に対する意見の関係

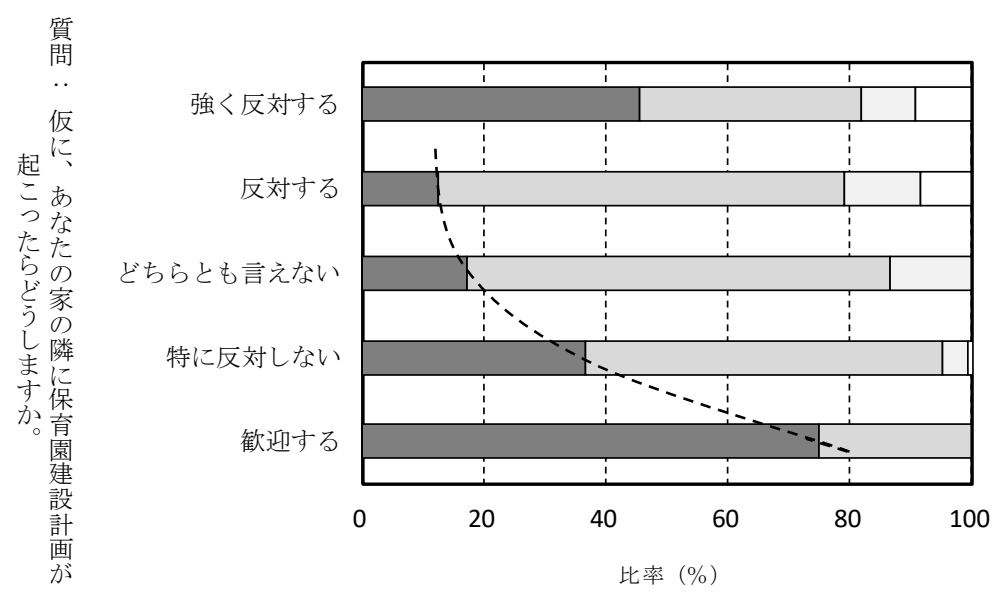

質問：子どもが大きな声を出して遊ぶことは、心身の発達に大切だと思いますか。

図 11 保育園建設反対意見と子どもの心身発達の意識との関係

説明と対応により、住民の不安を解消してゆくことが必要であると 言える。本調查により、そのことの重要性と可能性が改めて示され たと考える。

\section{5. あとがき}

この研究は JSPS 科研費（平成 $27 \sim 28$ 年度、挑戦的萌芽研究、課 題番号 JP15K12726、「子どもの声の受忍限度に対する評価基準の構 築に関する研究」、代表者・橋本典久) によって実施された。

\section{参考文献}

1) 大阪府：子ども施設と地域との共生に向けて -子ども施設環境配慮手引 書一, 2017 年 2 月、pp1-70

2) 橋本典久 : 保育園での子どもの遊び声に関する騒音測定調查結果, 日本建 築学会環境系論文集, 第 729 号, 2016 年 11 月, pp909-917

3）エム・アール・アイリサーチアソシエイツ㑣：少子高齢社会等調查検討事 業報告書 (厚生労働所委託「人口減少社会に関する意識調查」報告書), 2015 年 3 月

4) 橋本典久 : 東日本大震災の応急仮設住宅における近隣騒音問題に関する調 查研究，日本建築学会環境系論文集，第 693 号，2013 年 11 月, pp901-907 [2017 年 5 月 24 日原稿受理 2017 年 8 月 30 日採用決定］ 